\title{
Piedras de la arquitectura milanesa
}

\section{Stones used in Milan architecture}

\author{
$\underline{\text { R. Bugini }}^{(*)}$ y L. Folli(*)
}

Recepción/Received: 17-V-07

Aceptación/Accepted: 5-XI-07

Publicado online/Online publishing: 15-XII-07

\section{RESUMEN}

La ciudad de Milán se encuentra en una llanura de suelo arcilloso adecuado para la fabricación de ladrillos pero en la cual no hay yacimientos de rocas. No obstante, en las colinas y montañas circundantes, que están comunicadas con la ciudad mediante vías navegables naturales y artificiales, sí existe una abundante cantidad de piedra. Entre los tipos de piedra utilizados desde la época de los romanos se encuentran granitos, mármoles y gneises del valle de Ossola, dolomías del lago Mayor, calizas detríticas del valle de Ceresio (Lugano), areniscas de las colinas de la Brianza, calizas negras y mármoles del lago Como y conglomerados y areniscas de la garganta del río Adda. Tradicionalmente, los principales usos han sido la piedra de fábrica (todas ellas), fustes de columnas (granito), losas (mármol), molduras (dolomía, caliza) y ornamental (mármol, dolomía, caliza).

Palabras clave: Milán, arquitectura, piedra, cantera, mármol.

\section{INTRODUCCIÓN}

El tipo de piedra empleado para construir pueblos y ciudades depende en gran medida de las características geológicas de la zona. Podemos encontrar evidencias que
SUMMARY

The city of Milan lies in a plain with clayey soil well suited to brick-making, but no stone deposits. An ample supply of stone is available, however, in the surrounding hills and mountains, which are connected to the city via both natural and artificial waterways. The types of stone used since Roman times include: granite, marble and gneiss from Ossola Valley; dolomite from Lake Maggiore; detrital limestone from Ceresio Valley; sandstone from the Brianza Hills; black limestone and marble from Lake Como; and conglomerate and sandstone from the Adda river gorge. Traditionally, the chief uses have been dimension stone (all stones), column shafts (granite), slabs (marble), moulding (dolomite, limestone) and ornamental (marble, dolomite, limestone).

Keywords: Milan, architecture, stone, quarry, marble.

\section{INTRODUCTION}

The type of stone used to build towns and cities depends largely on the geological features of the surrounding region. Evidence of this assertion can be found in many

(*) Instituto CNR, Conservazione e Valorizzazione Beni Culturali, sezione Milano "Gino Bozza" (Milano, Italia) 
respaldan esta afirmación en muchos lugares del norte de Italia, especialmente en Lombardía, una región con una geología muy variada en la que los edificios históricos de todas las ciudades sirven de escaparate de los materiales locales tradicionales. Ya en el siglo XVII, autores como Scamozzi (1) hicieron hincapié en la importancia del uso de materiales locales para reducir los costes de la construcción: "Laonde sarà prudente consiglio il sapersi servire di quelle materie che producono i propri paesi o che d'altrove si trasportano con facilità" (Por tanto sería aconsejable utilizar materiales de la propia región o que puedan transportarse desde otras zonas con facilidad). Su papel de capital regional (Ducato di Milano) permitió a Milán emplear piedra de distintas partes de lo que actualmente es la mitad occidental de la región de Lombardía. La mitad oriental, sin embargo, perteneció hasta finales del siglo XVIII (1797) a la República de Venecia, una división que condicionó la disponibilidad de los materiales de construcción. La unidad territorial se alcanzó bajo el dominio austriaco al crearse el reino de Lombardía y Véneto (1815-1860) y se mantuvo a partir de entonces.

Un análisis de las rocas de una región precisa del estudio de sus orígenes geológicos, sus propiedades petrográficas y mineralógicas, su uso a lo largo de periodos históricos sucesivos, su deterioro relacionado con la composición y su textura. Tales análisis son fundamentales para la historia de los materiales de construcción y la arquitectura, y resultan muy útiles para la conservación del patrimonio. Pero al encontrarse a caballo entre la geología y la arquitectura, estos análisis no recibieron la debida atención durante mucho tiempo, ya que los geólogos estaban interesados principalmente en la litología y la estratigrafía, mientras que los arquitectos se centraban en el tipo y estilo de construcción. Las piedras de Lombardía y su uso en arquitectura fueron descritos por primera vez por Scamozzi (1) en el siglo XVII, y en el siglo XIX se publicaron varios estudios científicos (Breislak (2), Curioni (3), Jervis (4) y Salmojraghi (5)). Antes de la segunda guerra mundial se realizó un completo estudio en el que se describía el uso extendido de la piedra, pero los estudios más relevantes [los de Fagnani (7) y Rodolico (8)], datan de la segunda mitad del siglo $X X$.

\section{GEOLOGÍA}

La ciudad de Milán se encuentra en una gran llanura aluvial (el valle del río Po o Pianura Padana) limitada al norte por colinas (Prealpi) y montañas (Alpi Lepontine). Los depósitos de arcilla de esta llanura se utilizan para fabricar ladrillos; cantos calcáreos para fabricar cal; y arena y gravas para fabricar áridos para el mortero. Los tres tipos de roca (ígnea, sedimentaria o metamórfica), que cuentan con variedades útiles para la construcción, pueden places in northern Italy, particularly in Lombardy, a region with a widely varied geology where the historic buildings in every town are a showcase of traditional local materials. As early as the seventeenth century, authors such as Scamozzi (1) stressed the importance of using local materials to lower building costs: "Laonde sarà prudente consiglio il sapersi servire di quelle materie che producono i propri paesi o che d'altrove si trasportano con facilità" (Whence we would be well advised to use materials produced in our own region, and from elsewhere only if they can be readily conveyed). As regional capital (Ducato di Milano), Milan was able to use stone from different parts of what is now the western half of Regione Lombardia. Until the end of eighteenth century (1797), however, the eastern part of the region pertained to the Repubblica di Venezia, a division that determined the availability of building materials. Territorial unity was attained under Austrian rule, with the establishment of Regno Lombardo-Veneto (1815-1860), and maintained thereafter.

A survey of a region's stones calls for a study of the geological background, petrographic and mineralogical properties, use over successive historic periods, composition-related decay and texture. Such surveys are instrumental to the history of building materials and architecture and very useful for the conservation of heritage buildings. But inasmuch as they straddle geology and architecture, such surveys were long neglected, for geologists were interested primarily in lithology and stratigraphy, while architects focused on building type and style. The Lombard stones and their use in architecture were first described by Scamozzi (1) in the seventeenth century and a number of scientific studies were published in the nineteenth (Breislak (2), Curioni (3), Jervis (4) and Salmojraghi (5)). A comprehensive survey describing the widespread use of stone was conducted prior to World War II (6), but the most relevant studies [authored by Fagnani (7) and Rodolico (8)], date from the latter half of the twentieth century.

\section{GEOLOGY}

The city of Milan lies in a large alluvial plain (Po River valley or Pianura Padana) bounded on the north by hills (Prealpi) and mountains (Alpi Lepontine). The clay deposits on the plain are used to make brick, the limestone outcrops to make lime and the sand and gravel to make mortar. All three types of rock (igneous, sedimentary or metamorphic), with varieties useful for building, can be found in the surrounding hills and mountains. These 
encontrarse en las colinas y montañas circundantes. Estos materiales se transportan hasta la ciudad por lagos y ríos, así como por canales artificiales que datan de la Edad Media.

Hasta el siglo XX, la piedra destinada a Milán se extraía de seis zonas distintas:

1- Valle de Ossola, actualmente parte de la región del Piamonte pero bajo el Ducato di Milano hasta 1748.

2- Costa meridional del lago Mayor. 3- Valle de Ceresio (también conocido como Lugano). 4- Colinas de la Brianza. 5- Lago Como. 6- Garganta del río Adda.

\section{PROPIEDADES DE LAS PIEDRAS}

Se analizaron muestras extraídas de las canteras con un microscopio óptico (láminas delgadas) y por difracción de rayos $\mathrm{X}$ en muestras de polvo. La ubicación de las canteras se muestra en el mapa de la Figura 1.

\section{Valle de Ossola \\ Granitos (Graniti dei Laghi)}

1a. Baveno. Grano medio, cromatismo con predominio de rosa y blanco con puntos negros. Composición: cuarzo, ortoclasa, plagioclasa, biotita. Geología: intrusión de cuerpo magmático (plutonismo herciniano) en las rocas metamórficas (gneis y micoesquistos) de Serie dei Laghi que forman el monte Mottarone (de unos $10 \mathrm{~km}$ de largo por $3 \mathrm{~km}$ de ancho) en la margen occidental del lago Mayor $(9,10)$. Canteras situadas en la vertiente septentrional del monte Mottarone. Tamaño de los bloques: monolitos de hasta 13 metros de longitud. Usos: piedra de fábrica, fustes de columnas, dinteles, jambas. Deterioro: lajación con pérdida de material ante la capilaridad y la cristalización de sales, principalmente en los muros inferiores de los edificios afectados.

1b. Montorfano. Grano medio, cromatismo blanco y gris con puntos negros. Composición: cuarzo, ortoclasa, plagioclasa, biotita, sulfuro de hierro. Geología: cuerpo magmático que forma el monte Montorfano (de unos $2 \mathrm{~km}$ de diámetro) cerca de la desembocadura del río Toce (9, 10). Canteras situadas en la vertiente meridional del Montorfano.

Tamaño de los bloques y usos: los mismos que el granito de Baveno. Deterioro: lajación, puntos de oxidación alrededor de minerales sulfurosos.

\section{Mármoles}

1c. Candoglia. Grano medio, cromatismo con predominio rosa o blanco con vetas negras paralelas. Composición: principalmente calcita; también pueden aparecer cuarzo, materials are carried to the city over lakes and rivers, as well as along artificial waterways dating from the Middle Ages.

Until the twentieth century, stone for Milan was quarried from six different areas:

1- Ossola Valley, today part of the Piedmont region but under the Ducato di Milano until 1748.

2- Southern shore of Lake Maggiore. 3- Ceresio Valley. 4Brianza Hills. 5- Lake Como. 6- Adda river gorge

\section{STONE PROPERTIES}

Stone samples taken from the quarries were analyzed under an optical microscope (thin sections) and by X-ray powder diffraction. Quarry locations are shown on the map in Figure 1.

\section{Ossola Valley \\ Granites (Graniti dei Laghi)}

1a. Baveno. Medium grain, pink and white coloration with black spots. Composition: quartz, orthoclase, plagioclase, biotite. Geology: magmatic body (Hercynian plutonism) intrusion in the Serie dei Laghi metamorphic rocks (gneiss and mica schsist) that form Mount Mottarone (about $10 \mathrm{~km}$ long by $3 \mathrm{~km}$ wide) on the west bank of Lake Maggiore $(9,10)$. Quarries located on the northern slope of Mount Mottarone. Block size: monoliths up to 13 metres long. Use: dimension stone, column shafts, lintels, jambs. Decay: spalling and detachment caused by capillarity and salt crystallization, mainly on the lower walls of buildings.

1b. Montorfano. Medium grain, white and grey coloration with black spots. Composition: quartz, orthoclase, plagioclase, biotite, iron sulphides. Geology: magmatic body forming Mount Montorfano (about $2 \mathrm{~km}$ in diameter) near the mouth of the Toce River $(9,10)$. Quarries located on the southern slope of Montorfano.

Block size and use: same as in Baveno granite. Decay: spalling, rust spots around sulphide minerals.

\section{Marbles}

1c. Candoglia. Medium grain, pink or white coloration with dark parallel veins. Composition: mainly calcite; accessory minerals include quartz, muscovite and pyrite. 


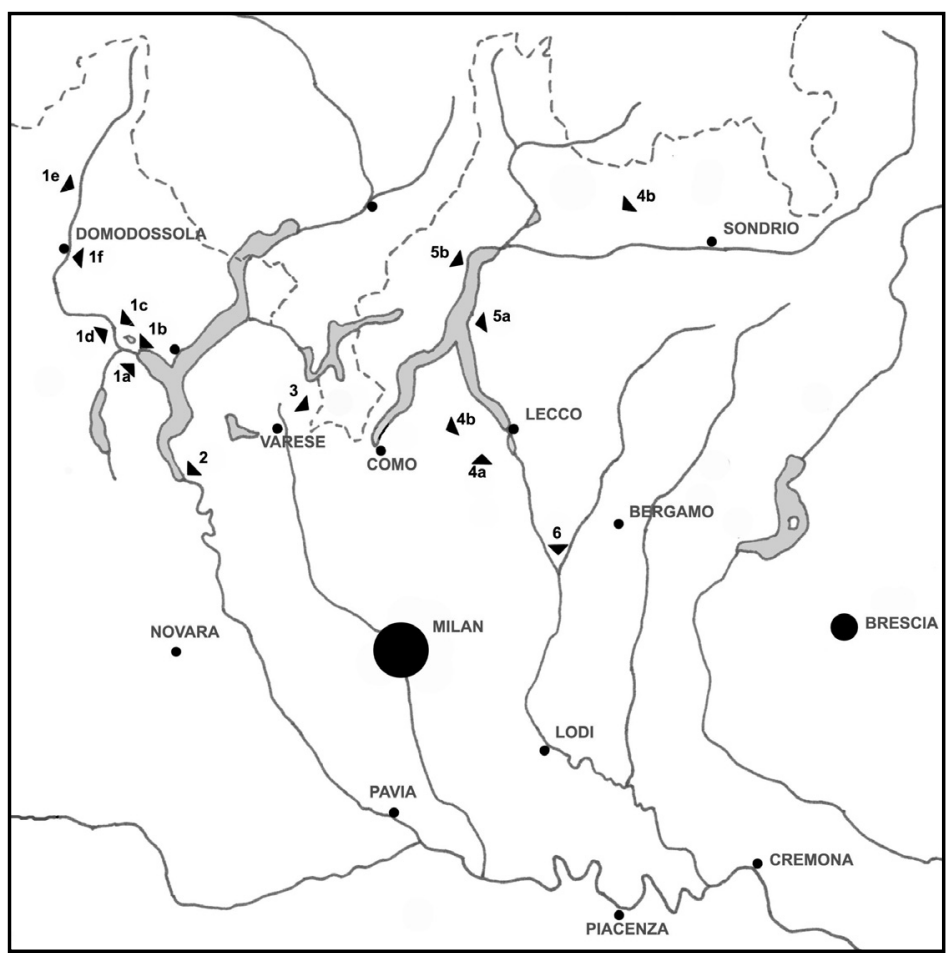

Figura 1. Mapa de Lombardía occidental con las fronteras nacionales y su hidrografía. Las principales canteras de piedra para construcción usada en Milán están numeradas como en el texto. 1. Valle de Ossola: a- granito de Baveno, b- granito de Montorfano, c- mármol de Candoglia, d- mármol de Ornavasso, e- mármol de Crevola, f- gneis de Serizzo; 2. Piedra de Angera; 3. Caliza de Viggiù y de Saltrio; 4. La Brianza: a- arenisca de Molera, b- bloques de Ghiandone (se muestra también el afloramiento próximo a Sondrio); 5. Lago Como: a- caliza de Varenna, b- mármol de Musso; 6 . Conglomerado y arenisca de Ceppo. Lombardía se divide en tres zonas geológicas. La primera empezando por arriba (Domodossola, Sondrio) es la zona alpina, que se caracteriza por las rocas metamórficas e ígneas (principalmente gneis, granito y diorita). La zona central (Varese, Como, Lecco y Bérgamo), es la zona prealpina, en la que predominan las rocas sedimentarias (principalmente caliza y arenisca). La tercera zona (Milán, Brescia, Pavia, Lodi, Cremona) es la llanura aluvial padana, que es la zona más baja de las tres.

Figure 1. Map of western Lombardy showing national boundaries and waterways. The major quarry areas for building stone used in Milan are numbered as described in the text. 1. Ossola Valley: a-Baveno granite, $b$-Montorfano granite, c-Candoglia marble, $d$-Ornavasso marble, e-Crevola marble, f-Serizzo gneiss; 2. Angera stone; 3. Viggiù and Saltrio limestone; 4. Brianza: a-Molera sandstone, b-Ghiandone boulders (the outcrop near Sondrio is also shown); 5. Lake Como: a-Varenna limestone, b-Musso marble; 6. Ceppo conglomerate and sandstone. Lombardy is divided into three geological zones: the first, from the top downward (Domodossola, Sondrio), is the alpine zone, characterized by metamorphic and igneous rocks (mainly gneiss, granite and diorite); in the second or central zone (Varese, Como, Lecco, Bergamo), the pre-alpine zone, sedimentary rocks prevail (mainly limestone and sandstone); the third or lower zone (Milan, Brescia, Pavia, Lodi, Cremona) is the Padanian alluvial plain.

moscovita y pirita. Geología: lentes de mármol (de unos $40 \mathrm{~m}$ de ancho) orientados de noreste a sudoeste, intercaladas en metapelitas y roca base de la zona de IvreaVerbano $(11,12)$. Canteras situadas en la vertiente oriental de la parte baja del Valle de Ossola. Tamaño de los bloques: 2,0 $\mathrm{m}^{3}$. Usos: piedra de fábrica, losas, fustes de columnas pequeñas, estatuas, ornamental. Deterioro: erosión con disolución de carbonato cálcico y alteración del perfil de la superficie en zonas expuestas a la lluvia, capa exterior de sulfato cálcico en zonas resguardadas en las que las gotas de agua humedecen la superficie de la piedra.

1d. Ornavasso. Grano grueso, cromatismo gris o rosa con vetas negras paralelas. Composición: principalmente calcita con cuarzo, moscovita y pirita. Geología: la misma
Geology: marble lenses (about 40 m wide) running from NE to SW, interbedded in metapelites and Ivrea-Verbano zone base rock $(11,12)$. Quarries located on the eastern slope of the lower Ossola Valley. Block size: 2,0 $\mathrm{m}^{3}$. Use: dimension stone, slabs, small column shafts, statuary, ornamental. Decay: erosion entailing dissolution of calcium carbonate and alteration of the surface profile in areas exposed to rain; outer layer of calcium sulphate in sheltered areas where water droplets moisten the stone surface.

1d. Ornavasso. Coarse grain, grey or pink coloration with parallel black veins. Composition: mainly calcite with quartz, muscovite and pyrite. Geology: same as for 
que para el mármol de Candoglia. Canteras situadas en la vertiente occidental de la parte baja del Valle de Ossola. Tamaño de los bloques: $2.0 \mathrm{~m}^{3}$. Usos: piedra de fábrica, losas, fustes de columnas pequeños. Deterioro: erosión, puntos de oxidación, capa exterior de sulfato cálcico.

1e. Crevola. Grano entre medio y fino, cromatismo gris o blanco con vetas marrones. Composición: dolomía, flogopita. Geología: lentes de mármol intercaladas en el manto del monte Leone, que forma parte de las unidades peninas inferiores $(11,13)$. Las canteras se encuentran en la parte baja del valle de Divedro (cerca de la parte alta del valle de Ossola). Tamaño de los bloques: monolitos de hasta 11 metros de longitud. Usos: piedra de fábrica, losas, fustes de columnas. Deterioro: erosión, capa exterior de sulfato cálcico.

\section{Gneises}

1f. Serizzo. Grano medio, fondo gris con bandas estrechas oscuras alternadas con otras claras o bien puntos blancos ovalados ("Augen"), foliación débil. Composición: feldespato potásico, cuarzo y micas. Geología: manto de Antigorio en las unidades peninas inferiores (9). Canteras dispersas por los valles de Antigorio y Formazza. Tamaño de los bloques: 2,0-5,0 $\mathrm{m}^{3}$. Usos: sillerías, piedra de fábrica, fustes de columnas. Deterioro: lajación.

\section{Costa meridional del lago Mayor. Dolomías}

Angera (pietra d'Angera). Grano muy fino, cromatismo rosa, amarillo o blanco, muy porosa. Composición: dolomía. Geología: formación de la Dolomia Principale (Triásico, Alpes meridionales) $(14,15)$. Canteras situadas en la margen más meridional del lago Mayor. Tamaño de los bloques: 2,0 m³. Usos: piedra de fábrica, fustes de columnas pequeñas, escultura, ornamental. Deterioro: erosión, exfoliación y separación, capa exterior de sulfato cálcico.

\section{Valle de Ceresio (Lugano)}

\section{Piedra caliza detrítica}

Viggiù (pietra di Viggiù). Oolítica, grano medio, cromatismo marrón (calcarenita). Composición: calcita, dolomía, trazas de cuarzo. Geología: formación de los Calcari Selciferi Lombardi (Jurásico, Alpes meridionales) (14). Canteras dispersas por una amplia zona al sur del lago Lugano. Tamaño de los bloques: 1,3-3,5 m³. Usos: fustes de columnas, piedra de fábrica, ornamental. Deterioro: erosión, capa exterior de sulfato cálcico.

Saltrio (pietra di Saltrio). Grano fino, cromatismo gris claro. Composición: calcita, dolomía, sílice. Geología, canteras, tamaño de bloques, usos y deterioro: los mismos que para la caliza de Viggiù.
Candoglia. Quarries located on the western slope of the lower Ossola Valley. Block size: $2.0 \mathrm{~m}^{3}$. Use: dimension stone, slabs, small column shafts. Decay: erosion, rust spots, outer layer of calcium sulphate.

1e. Crevola. Medium to fine grain, grey or white coloration with brown veins. Composition: dolomite, phlogopite. Geology: marble lenses interbedded in the Monte Leone nappe, which forms a part of the Lower Penninic Units $(11,13)$. Quarries are located in the lower Divedro Valley (near the upper part of Ossola Valley). Block size: monoliths up to 11 metres long. Use: dimension stone, slabs, column shafts. Decay: erosion, outer layer of calcium sulphate.

\section{Gneiss}

1f. Serizzo. Medium grain, narrow dark and alternating light bands or white oval spots against a grey ground (Augen), weak foliation. Composition: potassium feldspar, quartz and micas. Geology: Antigorio nappe in the Lower Penninic Units (9). Quarries scattered across the Antigorio and Formazza Valleys. Block size: 2.0-5.0 $\mathrm{m}^{3}$. Use: ashlars, dimension stone, column shafts. Decay: spalling.

\section{Southern shore of Lake Maggiore. Dolostones}

Angera (pietra d'Angera). Very fine grain, pink, yellow or white coloration; very porous. Composition: dolostone. Geology: Dolomia Principale formation (Triassic, Southern Alps) (14, 15). Quarries located in the southern-most bank of Lake Maggiore. Block size: $2.0 \mathrm{~m}^{3}$. Use: dimension stone, small column shafts, sculpture, ornamental. Decay: erosion, exfoliation and detachment, outer layer of calcium sulphate.

\section{Ceresio Valley \\ Detrital limestone}

Viggiù (pietra di Viggiù). Oolitic, medium grain, brown coloration (calcarenite). Composition: calcite, dolomite, traces of quartz. Geology: Calcari Selciferi Lombardi formation (Jurassic, Southern Alps) (14). Quarries scattered across a large area south of Lake Lugano. Block size: 1.3$3.5 \mathrm{~m}^{3}$. Use: column shafts, dimension stone, ornamental. Decay: erosion, outer layer of calcium sulphate.

Saltrio (pietra di Saltrio). Fine grain, light grey coloration. Composition: calcite, dolomite, chert. Geology, quarries, block size, use and decay: same as Viggiù. 


\section{Colinas de la Brianza}

\section{Arenisca}

4a. Molera. Grano entre medio y fino, cromatismo amarillo oscuro o gris, laminación entre plana y convoluta. Composición: cuarzo y moscovita compactados por cemento calcítico. Dos formaciones sedimentarias de turbidita: flysch de Bérgamo (Cretáceo, Camapaniano Santoniano superior) y arenisca de Sarnico (Cretáceo, Santoniano inferior - Turoniano) (16). Canteras dispersas por gran parte de las colinas de la Brianza, principalmente alrededor de Viganò (flysch de Bérgamo) y Oggiono (arenisca de Sarnico). Tamaño de los bloques: monolitos de hasta 4,5 metros de longitud. Usos: piedra de fábrica, fustes de columnas, ornamental. Deterioro: descascarillado del contorno con desprendimiento de partículas independiente de la disposición de los bancos, exfoliación, disgregación con desprendimiento de clastos causada por la disolución del cemento calcítico.

\section{Rocas ígneas y metamórficas}

4b. Granodiorita. Grano medio, cromatismo gris con puntos blancos. Composición: cuarzo, feldespato potásico, biotita. Geología: Intrusión del cuerpo magmático de Val Masino y Val Bregaglia (plutonismo alpino) en el basamento alpino meridional (17). En el pasado, los artesanos trabajaban los bloques erráticos que dejaron tras de sí los glaciares del Cuaternario en las inmediaciones de la llanura padana, muchos kilómetros más al sur del afloramiento donde se encuentran las canteras modernas. Tamaño de los bloques: 5,0 m³. Usos: sillerías, piedra de fábrica, fustes de columnas. Deterioro: lajación.

\section{Lago Como \\ Calizas}

5a. Varenna (Nero Varenna). Grano muy fino, cromatismo negro. Composición: calcita. Geología: formación de las calizas de Perledo y Varenna (Ladiniano, Triásico medio) en la orilla occidental del lago Como (18). Canteras alrededor de Varenna y cerca de la orilla del lago. Tamaño de los bloques: 0,05-0,25 m³. Usos: losas, ornamental. Deterioro: decoloración de negro a gris claro, erosión, capa exterior de sulfato cálcico.

\section{Mármoles}

5b. Musso. Grano entre medio y grueso, coloración gris o blanca. Composición: calcita, cuarzo, moscovita. Geología: lentes de mármol (de unos $100 \mathrm{~m}$ de ancho) orientados de este a oeste intercaladas en el gneis del basamento alpino meridional (zona de Dervio-Olgiasca) (11). Canteras cercanas a Musso en la orilla septentrional del lago Como. Tamaño de los bloques: 4,0 m³. Usos: piedra de fábrica, losas, estatuas, ornamental. Deterioro: erosión, capa exterior de sulfato cálcico.

\section{Brianza Hills \\ Sandstone}

4a. Molera. Medium to fine grain, dark yellow or grey coloration, planar to convoluted laminations. Composition: quartz and muscovite bonded by calcite cement. Two turbidite sediment formations: Bergamo flysch (Cretaceous, Campanian - upper Santonian) and Sarnico sandstone (Cretaceous, lower Santonian Turonian) (16). Quarries scattered across a large portion of the Brianza Hills, mostly around Viganò (Bergamo flysch) and Oggiono (Sarnico sandstone). Block size: monoliths up to 4,5 metres long. Use: dimension stone, column shafts, ornamental. Decay: contour scaling with detachment of flakes not linked to the bedding pattern, exfoliation, disaggregation with detachment of clasts caused by the dissolution of the calcite cement.

\section{Igneous and metamorphic rocks}

4b. Granodiorite. Medium grain, grey coloration with white spots. Composition: quartz, potassium feldspar, biotite. Geology: Val Masino and Val Bregaglia (Alpine plutonism) magmatic body intruding the South Alpine Basement (17). In times past, craftsmen worked the glacial erratics or boulders left behind by Quaternary glaciers found near the Padania plain, many kilometres south of the stone outcrop where modern quarries are located. Block size: $5.0 \mathrm{~m}^{3}$. Use: ashlars, dimension stone, column shafts. Decay: spalling.

\section{Lake Como Limestone}

5a. Varenna (Nero Varenna). Very fine grain, black coloration. Composition: calcite. Geology: Calcari di Perledo e Varenna formation (Ladinian, middle Triassic) on the west shore of Lake Como (18). Quarries around Varenna and near the lakeshore. Block size: 0.05-0.25 $\mathrm{m}^{3}$. Use: slabs, ornamental. Decay: colour change from black to light grey, erosion, outer layer of calcium sulphate.

\footnotetext{
Marble

5b. Musso. Medium to coarse grain, grey or white coloration. Composition: calcite, quartz, muscovite. Geology: marble lenses (about $100 \mathrm{~m}$ wide) running from east to west and interbedded in South Alpine Basement gneiss (Dervio-Olgiasca zone) (11). Quarries near Musso on the northern shore of Lake Como. Block size: $4.0 \mathrm{~m}^{3}$. Use: dimension stone, slabs, statuary, ornamental. Decay: erosion, outer layer of calcium sulphate.
} 
Dispersos por la zona hay bloques de granito y granodiorita o gneis procedentes de los depósitos glaciales. Tamaño de los bloques: 5,0 m³. Usos: sillerías, piedra de fábrica, fustes de columnas.

\section{Garganta del río Adda} Conglomerados y areniscas

Ceppo dell'Adda. Varios colores sobre fondo amarillento. Composición: cuarzo, calcita y silicatos compactados por cemento calcítico. Geología: Depósitos fluviales del Cuaternario (Plioceno superior - Pleistoceno inferior) (19, 20). Los principales afloramientos se encuentran en las gargantas formadas por los ríos Adda y Brembo. Pueden identificarse tres variedades: Ceppo rustico (conglomerado, empleado para piedra de fábrica), Ceppo mezzano (arenisca con fragmentos de roca, utilizada para piedra de fábrica), Ceppo gentile (arenisca, usada para molduras y escultura ornamental). Las canteras estaban dispersas a lo largo de las márgenes del río cerca de Trezzo d'Adda. Tamaño de los bloques: 5,0 m³. Usos: sillerías, piedra de fábrica, estatuas, ornamental. Deterioro: erosión, disgregación.

\section{CRONOLOGÍA DEL USO DE LA PIEDRA EN LA CONSTRUCCIÓN}

Se ha estudiado un número considerable de edificios históricos de Milán con motivo de la investigación, con fines de conservación, realizada en los últimos veinticinco años por el Instituto de Conservación y Valoración del Patrimonio Cultural. Los resultados de esta investigación y de las inspecciones oculares han proporcionado una amplia visión sobre el uso de la piedra a lo largo de un periodo de dos mil años.

\section{Periodo romano}

La piedra de fábrica utilizada para construir las estructuras romanas (teatro del siglo I d. de C. y anfiteatro del siglo II d. de C.) consta de monolitos de 1-2 $\mathrm{m}^{3}$ de conglomerado de Ceppo dell'Adda y de granodiorita de Ghiandone. Los cimientos se hacían con cantos y áridos de granito, gneis, pórfido, caliza o arenisca procedentes de la sedimentación fluvial, mezclados con mortero de cal.

El mármol local blanco y gris, como el mármol de Musso (columnata junto a la iglesia de San Lorenzo, Figura 2), o la piedra procedente de los Alpes Apuanos (Luni, provincia de Carrara) (21), las islas griegas o la costa turca del Egeo (22) se utilizaron con fines ornamentales (molduras, esculturas) y de solado. Estos elementos arquitectónicos se encontraban por todo el antiguo poblado romano.

A pesar de las largas distancias entre la cantera y el lugar de la obra, los habitantes romanos también empleaban
Individual granite and granodiorite or gneiss boulders from glacial deposits are scattered across the area. Block size: $5.0 \mathrm{~m}^{3}$. Use: ashlars, dimension stone, column shafts.

\section{Adda river gorge Conglomerates and sandstone}

Ceppo dell'Adda. Multi-colour against a yellowish ground. Composition: quartz, calcite and silicates bonded by calcite cement. Geology: Quaternary fluvial deposits (upper Pliocene - lower Pleistocene) $(19,20)$. The major outcrops are located on the gorges formed by the Adda and Brembo Rivers. Three varieties can be identified: Ceppo rustico (conglomerate, used for dimension stone), Ceppo Mezzano (sandstone with pebbles, used for dimension stone), Ceppo gentile (sandstone, used for moulding and ornamental sculpture). The quarries were scattered along the river banks near Trezzo d'Adda. Block size: $5.0 \mathrm{~m}^{3}$. Use: ashlars, dimension stone, statuary, ornamental. Decay: erosion, disaggregation.

\section{BUILDING STONE CHRONOLOGY}

A substantial number of historic buildings in Milan have been studied on the occasion of the conservation research conducted in the last twenty five years by the Cultural Heritage Conservation and Valuation Institute. The results of this research and visual inspections sketch the broad outlines of stone use over a two thousand-year period.

\section{Roman period}

The dimension stone used to build Roman structures (first century CE theatre and second century CE amphitheatre) consists in 1-2-m3 Ceppo dell'Adda conglomerate and Ghiandone granodiorite monoliths. Foundations were made of granite, gneiss, porphyry, limestone or sandstone fluvial sediment cobbles and pebbles, mixed with lime mortar.

Local white and grey marble such as Musso marble (colonnade alongside St Lawrence Church, Figure 2) or stone from the Apuanian Alps (Luni, province of Carrara) (21), the Greek islands or the Turkish Aegean coast (22) were used for ornamental purposes (mouldings, sculptures) and flooring. These architectural elements were found throughout the ancient Roman city.

Despite the long distances from quarry to building site, the Roman inhabitants also used stone from what is now 


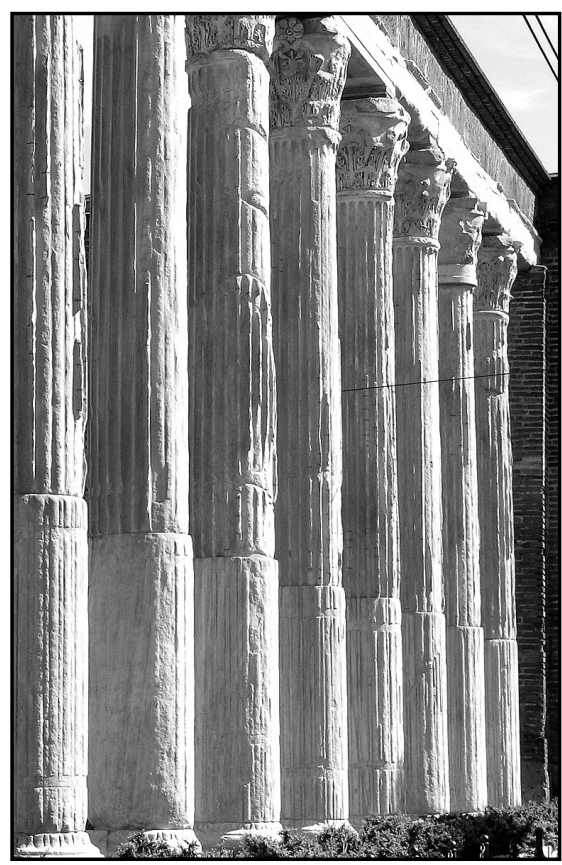

Figura 2. Columnata romana junto a la iglesia de San Lorenzo: los capiteles y fustes de las columnas son de mármol de Musso; el entablamento inferior de granodiorita de Ghiandone o de mármol de Musso, y entablamento superior de ladrillo.

Figure 2. Roman colonnade alongside St Lawrence Church: capitals and shafts are made of Musso marble; the lower entablature of Ghiandone granodiorite or Musso marble and the upper entablature of brick.

piedra de lo que ahora es el noreste de Italia, tales como caliza bioclástica de Aurisina, traquita de las colinas Euganeas (provincia de Padua) (23) y la caliza con nódulos rojos (Rosso ammonitico) de Verona (24). La cantera de Aurisina, por ejemplo, se encuentra en una región cárstica a $350 \mathrm{~km}$ al este de Milán. La caliza de Aurisina se usaba para piedra de fábrica o en estelas; la traquita, para pavimentar los caminos, y la caliza roja, con fines ornamentales.

El mármol procedente de lugares como Grecia (Cipollino; Porfido serpentino verde, Rosso antico), Turquía (Pavonazzetto), Egipto (Porfido rosso antico) y Túnez (Giallo antico) se utilizaba comúnmente para pavimentación y para recubrimiento de muros (25).

\section{Antigüedad tardía}

Los comienzos de la era cristiana (siglos IV y V) se caracterizaron por la construcción de grandes edificios de ladrillo, como las iglesias de San Lorenzo, Santa Tecla, San Simpliciano, San Juan de Conca y San Nazario. La piedra de fábrica, que se usaba sólo en los elementos inferiores, procedía de edificios romanos: Ghiandone en Santa Tecla, San Nazario y San Simpliciano y Ceppo en San Lorenzo. Estas piedras tenían un tamaño considerable: $2 \mathrm{~m}$ de largo, $1 \mathrm{~m}$ de ancho y 0,5 $\mathrm{m}$ de alto. Los solados eran de caliza negra de Varenna y mármol blanco o cali- northeastern Italy, including Aurisina bioclastic limestone, trachyte from the Euganean Hills (province of Padua) (23) and nodular red Verona limestone (Rosso ammonitico) (24). The Aurisina quarry, for instance, is in a karstic region $350 \mathrm{~km}$ east of Milan. Aurisina was used for dimension stone or in stelae, trachyte for paving roads and red limestone for ornamental purposes.

Coloured marbles from places such as Greece (Cipollino, Porfido serpentino verde, Rosso antico), Turkey (Pavonazzetto), Egypt (Porfido rosso antico) and Tunisia (Giallo antico) were widely used for flooring and wall veneering (25).

\section{Late antiquity}

The early Christian period (4th - 5th centuries) was characterized by the erection of large brick buildings such as St Lawrence, St Tecla, St Simplicianus, St John of Conca and St Nazarius Churches. Dimension stone, which was used on the lower members only, was taken from Roman buildings: Ghiandone on St Tecla, St Nazarius and St Simplicianus, Ceppo on St Lawrence. Substantial in size, these stones measure $2.0 \mathrm{~m}$ long, 1.0 wide and 0.5 high. Floors were tiled with black limestone from Varenna and white marble or limestone from Roman buildings (St John 
za procedente de edificios romanos (baptisterio de San Juan e iglesia de Santa Tecla, ambos del siglo IV).

\section{Románico}

Durante los dos siglos siguientes se construyeron numerosas iglesias, todas ellas con ladrillo y piedra reutilizada. Ceppo y Ghiandone se colocaban sobre todo en los elementos inferiores, como en las iglesias de San Ambrosio (Figura 3), San Vicente de Prato y San Eustorgio o en el campanario de San Sátiro. En la restauración románica de las iglesias de San Simpliciano y de San Nazario también
Baptistery and St Tecla Church, both from the fourth century).

\section{Romanesque}

A number of churches were built during the two centuries following on the first millennium, all with brick and reused stone. Ceppo and Ghiandone were placed mainly on the lower members such as in St Ambrose (Figure 3), St Vincent of Prato and St Eustorgius Churches and the St Satyrus belfry. In the Romanesque restoration of St Simplicianus and St Nazarius Churches, Ceppo was also

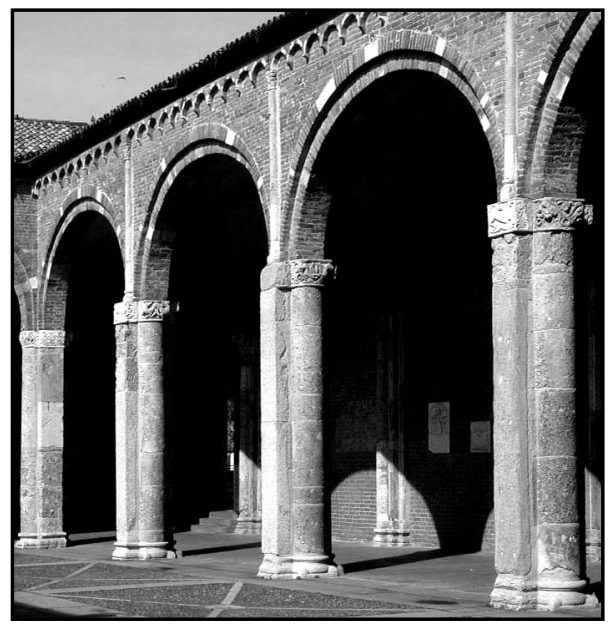

Figura 3. Atrio de la iglesia de San Ambrosio (siglo XI): traquita procedente de las colinas Euganeas, granodiorita de Ghiandone y conglomerado de Ceppo tomadas de edificios romanos (pilas), y piedra de Angera (capiteles).

Figure 3. St Ambrose Church atrium (eleventh century): trachyte from the Euganean hills, Ghiandone granodiorite and Ceppo conglomerate taken from Roman buildings (piers); Angera stone (capitals).

se usó Ceppo en los pilares en que se apoyan las bóvedas de crucería. Los mejores ejemplos de este uso del ladrillo se encuentran en dos estructuras gigantescas: el Castillo de Sforza (Castello Sforzesco), comenzado en 1358 y restaurado a principios de 1447, y el edificio del Hospital Mayor (Ospedale Maggiore), que se inició en 1456 según proyecto de Antonio Averulino, también conocido como Filarete. En el primero, se usó piedra de fábrica de Serizzo en los zócalos, mientras que en el segundo se colocaron ornamentos de terracota alrededor de ventanas y arcos y se utilizaron fustes de columna de Serizzo en los pórticos.

Fue en este periodo cuando se combinaron por primera vez piedras de distintos colores, como en la fachada de la Loggia degli Osii (1316), construida con caliza negra de Varenna y mármol rosa de Candoglia. También era frecuente mezclar mármol negro y blanco, como se hizo en la iglesia de Santa María de Brera (alrededor de 1350, destruida en 1809) y la catedral de Santa María la Mayor used in the piers supporting the ribbed vaults. The best examples of the use of brickwork are found on two huge structures, Sforza Castle (Castello Sforzesco), begun in 1358 and restored beginning in 1447, and the Main Hospital building (Ospedale Maggiore), begun in 1456 to a design by Antonio Averulino, also known as Filarete. In the former, Serizzo dimension stones were used on the socles, while the latter had terracotta ornaments around the windows and arches and Serizzo column shafts in the porticos.

It was in this period that stones of different colours were first combined, such as on the Loggia degli Osii facade (1316), built with Varenna black limestone and Candoglia pink marble. Another common mix was black and white marble, used on St Mary of Brera Church (circa 1350, destroyed in 1809) and St Mary Major cathedral (destroyed in 1683 but known from descriptions, engravings and 
(destruida en 1683, conocida por descripciones, grabados e impresos). La fachada de Santa María de Brera se atribuye a Giovanni de Balduccio, de Pisa, ciudad en la que se encuentra este diseño bicolor en muchas iglesias medievales (la catedral, San Pablo de Ripa d'Arno, Santa Catalina...).

\section{La catedral gótica}

La construcción del Duomo, la catedral gótica realizada completamente en mármol de Candoglia, comenzó en 1386 y duró varios siglos (Figura 4). De manera excepcional, en el Duomo el mármol no sólo se usó en los elementos ornamentales (esculturas, pináculos y agujas) sino también como piedra de fábrica en muros, contrafuertes y sus cincuenta y dos pilares de 24 metros de alto (hasta arriba del capitel). Esta piedra también era conocida por los romanos (estelas y placas), pero debido a las enormes cantidades de material necesario para la catedral, el mármol tuvo que extraerse de canteras a ambos lados del valle de Ossola (Candoglia al este y Ornavasso al oeste). La piedra de fábrica de Serizzo se utilizó en el zócalo, mientras que los núcleos de los pilares de mármol se hicieron con trozos de piedra y mortero. prints). The St Mary of Brera facade is attributed to Giovanni de Balduccio, an artist from Pisa, where this two-colour design is found on many Medieval churches (Duomo, St Paul of Ripa d'Arno, St Catherine and so on.).

\section{The gothic cathedral}

Construction on the Duomo or gothic cathedral, made entirely of Candoglia marble, was begun in 1386 and lasted for several centuries (Figure 4). Exceptionally, in the Duomo marble was used not only for ornamental elements - sculptures, pinnacles and spires - but also as dimension stone on walls, buttresses and fifty two piers 24 metres tall (to the top of the capital). This stone was also known to the Romans (stelae and plaques), but with the vast amounts of material required for the cathedral, marble had to be quarried from sites in both the eastern (Candoglia) and western (Ornavasso) Ossola Valley. Serizzo dimension stones were used on the socle, while the cores of the marble piers were built with stone fragments and mortar.

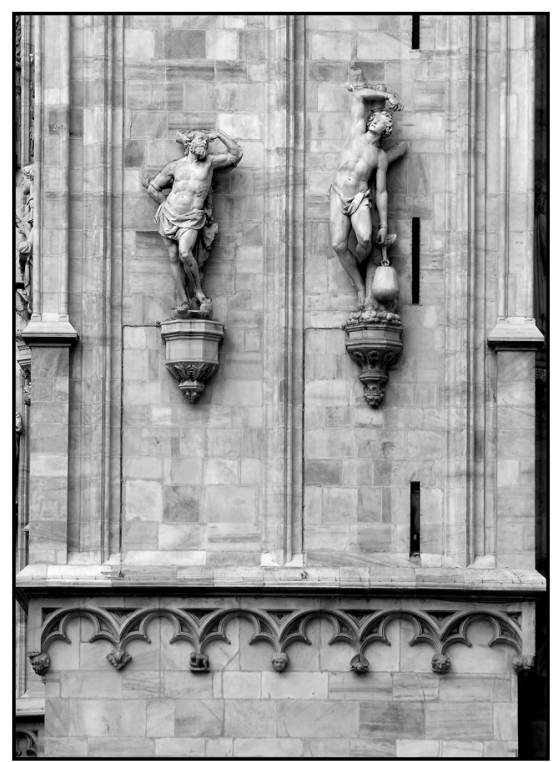

Figura 4. Nave sur del Duomo (siglo XIV): piedra, escultura y ornamentos de mármol de Candoglia.

Figure 4. South nave of the Duomo (14th century): Candoglia marble stonework, sculptures and ornaments.

\section{Renacimiento}

El Renacimiento supuso un cambio espectacular en las fachadas de los edificios de Milán, pasándose del ladrillo a piedra, en la mayoría de los casos de varios colores. En esta arquitectura tan sofisticada, la piedra blanda como la dolomía de Angera se utilizó para jambas de portales y

\section{Renaissance}

The Renaissance brought a dramatic change in the facades on Milanese buildings, from brick to - mostly multicoloured - stone. In this sophisticated architecture, soft stone such as Angera dolostone was used for portal and window jambs, mouldings, bas-reliefs and sculptures. 
ventanas, molduras, bajorrelieves y esculturas. Pueden encontrarse ejemplos en las iglesias de Santa Maria presso San Satiro (1478) y Santa Maria delle Grazie (1493), ambas de Bramante. Este tipo de piedra ya había sido utilizado por los romanos (estelas y losas) y en la Edad Media (los capiteles del siglo $X$ de la iglesia de Santa Maria d'Aurona). Debido a su muy alta porosidad, esta dolomía ha sufrido pérdidas de material tan importantes que algunas de las tallas han desaparecido por completo (26).

A principios del siglo XVI se introdujeron monolitos de granito rosa de Baveno y granito blanco de Montorfano (Graniti dei Laghi) para fustes de columnas. En las columnas se utilizaban normalmente tres piedras distintas: granito en el fuste, mármol calcítico de Ornavasso con veta negra (Grigio Boden) en el pedestal y caliza marrón de Viggiù en el capitel. Estos tipos de granito aparecieron por primera vez en los fustes de las columnas del pórtico de San Pedro, en el claustro de Gessate (1509) y en las pilastras de la fachada de la Capella Trivulzio (Figura 5, 1512) de Bramantino. Los romanos no utilizaban este granito sino granito de Aswan y de Mons Claudianus (Gebel Fatireh) para sus monolitos, así como mármol griego del tipo Cipollino y Fior di Pesco procedentes de la isla de Evia.

\section{Clasicismo}

Esta época se caracterizó por la vuelta al Ceppo y el uso a gran escala del granito. Las distintas calidades de Ceppo se aplicaban con distintos fines: conglomerado en zócalos y arenisca en ventanas. Así ocurrió en los palacios de los Giureconsulti (1561), de Marino (1553, Figura 6) y de Omenoni (565) y en las iglesias de San Sebastián (de Pellegrino Tibaldi, 1577) y San Alejandro (de Lorenzo

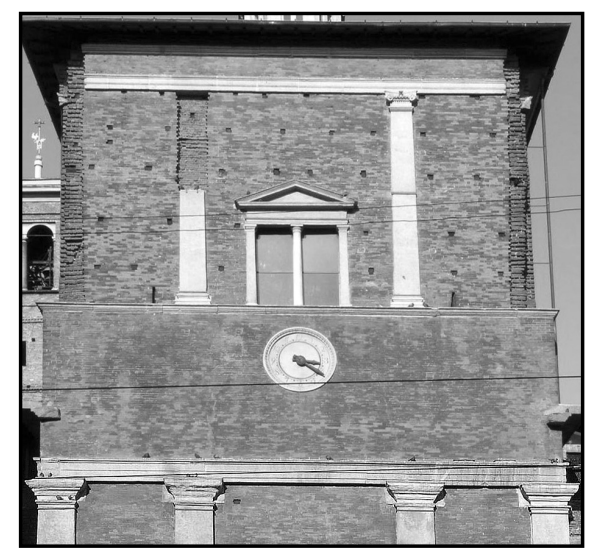

Figura 5. Capilla de Trivulzio (Bramantino, 1512): pilastras de granito de Montorfano y muros de ladrillo.

Figure 5. Trivulzio Chapel (Bramantino, 1512): Montorfano granite pilasters and brick walls.
Examples are to be found in Bramante's Sta Maria presso S. Satiro (1478) and Sta Maria delle Grazie (1493) Churches. This type of stone had been used by the Romans (stelae, slabs) and in the Middle Ages (the tenth century capitals on Sta Maria di Aurona Church). Due to its extreme porosity, this stone has undergone such extensive surface scaling that some of the carvings have disappeared altogether (26).

Baveno pink and Montorfano white granite (Graniti dei Laghi) monoliths for column shafts were introduced in the early sixteenth century. Three different stones were typically used on columns: granite in the shaft, Ornavasso grey-veined silicate marble (called Grigio Boden) in the base and brown Viggiù limestone in the capital. These types of granite first appeared on the column shafts in St Peter's portico in the Gessate Cloister (1509) and the facade parastas on Bramantino's Cappella Trivulzio (Figure 5, 1512). The Romans used not this granite but rather Aswan and Mons Claudianus (Gebel Fatireh) granite for their monoliths, as well as Greek marble such as Cipollino and Fior di Pesco from Euboea Island.

\section{Classicism}

This period was characterized by a return to Ceppo and the large-scale use of granite. Different qualities of Ceppo were applied for different purposes: conglomerate in socles and sandstone in windows, such as in the Giureconsulti (1561), Marino (1553, Figure 6) and Omenoni (1565) Palaces and Pellegrino Tibaldi's St Sebastian (1577) and Lorenzo Binago's St Alexander

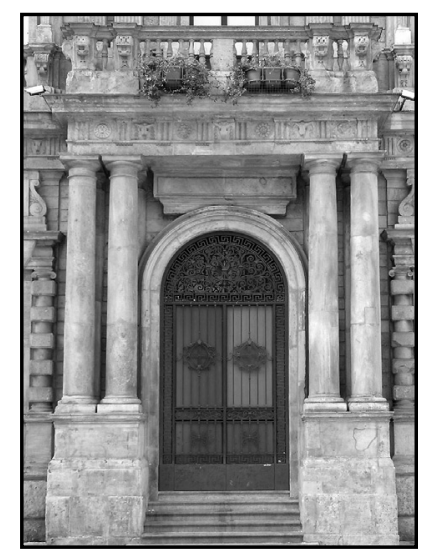

Figura 6. Portal del Palacio de Marino (G. Alessi, 1572): zócalo, plintos, columnas y entablamento de Ceppo (conglomerado y arenisca).

Figure 6. Portal on Marino Palace (G. Alessi, 1572): Ceppo (conglomerate and sandstone) s ocle, plinths, columns and entablature. 
Binago, comenzada en 1601). Otras piedras muy utilizadas en esta época fueron el Grigio Boden de la elaborada fachada y el pórtico del santuario de Santa María de los Milagros (1572) o la dolomía de Angera en los tambores de las columnas y en muros como en las iglesias de San Fidel (1569), San Rafael (1575) y Certosa di Garegnano (1577). Siguió aumentando el número de fustes monolíticos de granito en pórticos y de logias en los patios porticados, como atestiguan el Seminario Arzobispal (1602), el Colegio Helvético (1608) y los palacios de Litta (1648) y Stelline (1652). Para la fachada del Duomo se eligió granito rosa de Baveno. El diseño de Pellegrino Tibaldi, aprobado tras décadas de discusiones, precisaba diez fustes de columna de $19,5 \mathrm{~m}$. El primero se preparó en la cantera (1628), pero al ser demasiado pesado para los carruajes de la época, el proyecto finalmente se abandonó (27).

\section{Barroco}

Francesco Maria Ricchino, el arquitecto milanés más importante del siglo XVII y encargado de la construcción de la catedral, usó granito en los fustes de las columnas en patios y puertas monumentales, en molduras de la fachada y como piedra de fábrica en los zócalos. La mayoría de las innovadoras iglesias de Ricchino desaparecieron con el paso de los siglos, pero las que aún permanecen en pie dan fe de la importancia del granito en sus diseños: la iglesia de San José (1607), una fachada cóncava con un balcón convexo central en el Colegio Helvético, el Palacio de Annoni (1631), el enorme patio central del Hospital Mayor (Ospedale Maggiore, 1625) donde se empleó piedra de Angera en las esculturas ornamentales (Figura 7), la iglesia de San Juan de Case Rotte (1645), los fustes de columnas geminados del patio del Palacio de Brera con dos órdenes superpuestos (1651) y la iglesia de Santa María de la Puerta (1652). El ejemplo de Ricchino fue seguido por sus contemporáneos en iglesias como San Pablo Converso (1613), San Vito al Pasquirolo (1621) y Santa María Podone (1626).

\section{Altares barrocos \\ Durante el siglo XVII y parte del siglo XVIII se construye- ron numerosos altares en iglesias y capillas. Los más ela- borados tenían columnas y frontones espléndidamente decorados con molduras, esculturas, balaustradas y esca- leras. La piedra de colores que se empleaba en estos altares casi nunca cumplía con la regla sobre el uso de piedras locales (Figura 8).}

-Rosso di Arzo, Broccatello y Macchiavecchia se extraían en Arzo, una región de Suiza (cantón Tesino) cercana a Viggiù y Saltrio pero perteneciente al cantón Tesino desde el siglo XVI. El Rosso di Arzo es una caliza roja raramente moteada con puntos o vetas blancas; el Broccatello es una caliza fosilífera de color violeta y la Macchiavecchia es una (begun in 1601) Churches. Other stones popular in this period included Grigio Boden in the highly decorated facade and portico of St Mary of Miracles Sanctuary (1572) or Angera dolostone in column drums and walls such as in St Fidel (1569), St Raphael (1575) and Certosa di Garegnano Churches (1577). The number of monolithic granite shafts in porticos and loggias in colonnaded courtyards continued to grow, as attested by the Archbishopric Seminary (1602), Helvetic College (1608) and Litta (1648) and Stelline (1652) Palaces. Bavenoi pink granite was chosen for the facade on the Duomo. Pellegrino Tibaldi's design, approved after decades of quarrelling, called for ten 19.5-metre column shafts. The first was prepared at the quarry (1628), but when it proved to be too heavy for the existing carriages, the project was finally abandoned (27).

\section{Baroque}

Francesco Maria Ricchino, the most relevant seventeenth century Milanese architect and master builder of the cathedral, used granite on column shafts in courtyards or portals, in facade mouldings and as dimension stone on socles. Most of Ricchino's innovative churches were destroyed over the centuries, but the ones still standing attest to the role of the granite in his designs: St Joseph Church (1607), a concave facade with a central convex balcony on the Helvetic College (1627), Annoni Palace (1631), the vast central courtyard of the Main Hospital (Ospedale Maggiore, 1625) where Angera stone was employed for ornamental sculptures (Figure 7), St John of Case Rotte Church (1645), the coupled column shafts in the Brera Palace courtyard with two superimposed orders (1651), St Mary of the Door Church (1652). Ricchino's example was followed by his contemporaries in churches such as St Paul the Convert (1613), St Vito al Pasquirolo (1621) and St Mary Podone (1626).

\section{Baroque altars}

A host of altars were built in churches and chapels throughout the seventeenth and into the eighteenth century. The most elaborate had columns and pediments lavishly ornamented with mouldings, sculptures, balustrades and staircases. The coloured stone used in these altars almost always contravened the local stone rule (Figure 8).

-Rosso di Arzo, Broccatello and Macchiavecchia were quarried in Arzo, a region of Switzerland (Ticino Canton) near Viggiù and Saltrio but pertaining to Ticino Canton since the sixteenth century. Rosso di Arzo is a red limestone with occasional white veins or spots; Broccatello is a fossiliferous purple limestone and Macchiavecchia is a 


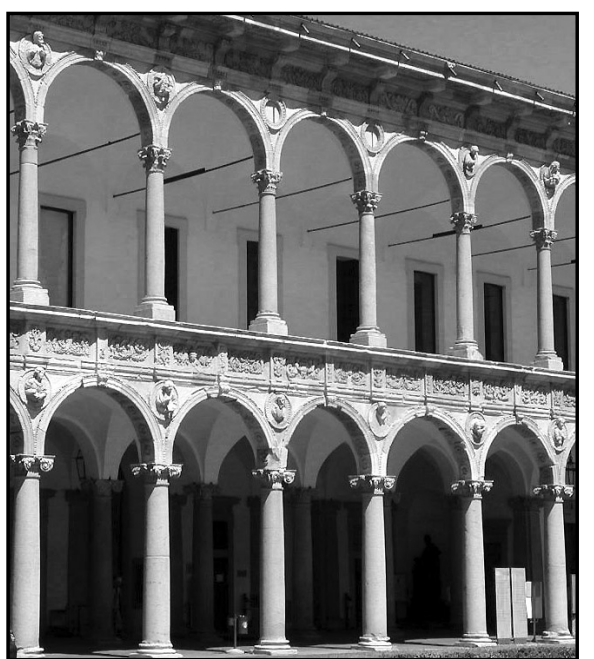

Figura 7. Patio (F. M. Ricchino, principios del siglo XVII) en el Hospital Mayor (Ospedale Maggiore), en el que pueden verse el pórtico y la logia (fustes de las columnas) en granito de Baveno o de Montorfano, con caliza de Viggiù (capiteles), Grigio Boden (pedestales) y piedra de Angera (esculturas y molduras).

Figure 7. Courtyard (F.M. Ricchino, early seventeenth century) in Main Hospital (Ospedale Maggiore), showing Baveno or Montorfano granite portico and loggia (column shafts), with Viggiù limestone (capitals), Grigio boden (bases) and Angera stone (sculptures and mouldings).

brecha de varios colores, prevaleciendo las manchas de color rojo, amarillo, marrón y gris (14).

-Arabescato orobico: caliza veteada de color rojo y blanco o gris y blanco procedente del valle de Brembana (provincia de Bérgamo) (28).

-Occhiadino: estromatolito gris con vetas blancas onduladas procedente del valle de Camónica (provincia de Brescia) (29).

-Giallo di Siena: mármol de color amarillo con vetas onduladas oscuras procedente de Montagnola Senese (provincia de Siena, Toscana) (30).

-Rosso di Francia: caliza de color rojo oscuro con vetas blancas procedente de Caunes en Minervois (Aude, Francia) (31).

-Broccatello di Spagna: caliza bioclástica de color amarillo y violeta procedente de Tortosa (Tarragona, España) (32).

-Alabastro-calcita (Travertine) de diversos colores procedente de Induno Olona (provincia de Varese) o del valle de Seriana (33).

-Oficalcitas de color verde y blanco procedentes del Piamonte o del valle de Aosta (34).

-Mármol blanco o gris procedente de los Alpes Apuanos (provincias de Carrara y Massa, Toscana) (21).

La parte delantera de los altares, por su parte, contiene piedra incrustada con numerosas gemas de colores y semipreciosas engastadas en caliza negra o mármol blanco.

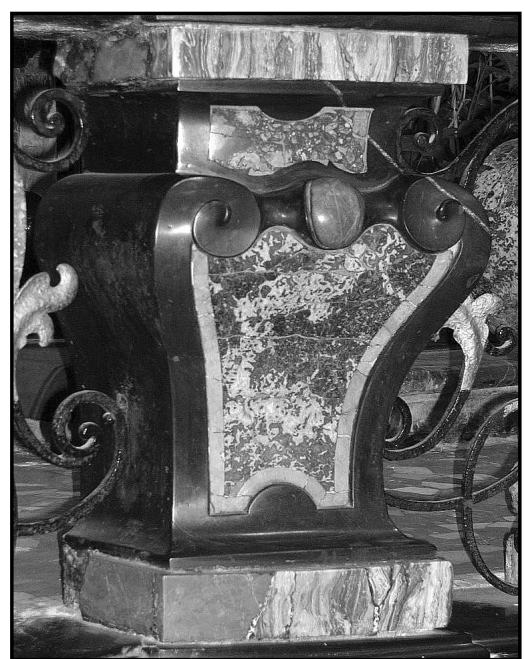

Figura 8. Iglesia de San Bernardino alle Ossa, balaustrada izquierda del altar (fines del siglo XVIII): pequeña pila de caliza negra con elementos de Occhiadino (centro) y Arabescato orobico (superior e inferior).

Figure 8. S. Bernardino alle Ossa Church, left altar balustrade (late eighteenth century). Small black limestone pier with Occhiadino (centre) and Arabescato orobico (top and bottom) elements.

multi-coloured breccia with a prevalence of red, yellow, brown and grey patches (14).

-Arabescato orobico: a streaked red and white or grey and white limestone from Brembana Valley (province of Bergamo) (28).

-Occhiadino: a grey stromatolite limestone with curved white veins from Camonica Valley (province of Brescia) (29).

-Giallo di Siena: a yellow marble with dark undulated veins from Montagnola Senese (province of Siena, Tuscany) (30).

-Rosso di Francia: a dark red limestone with white veins from Caunes en Minervois (Aude, France) (31).

-Broccatello di Spagna: a yellow and purple bioclastic limestone from Tortosa (Tarragona, Spain) (32).

-Alabaster-calcite (Travertine) of different colours from Induno Olona (province of Varese) or the Seriana Valley (33).

-Green and white ophicalcites from Piedmont or Aosta Valley (34).

-White or grey marble from the Apuanian Alps (provinces of Carrara and Massa, Tuscany) (21).

The front of the altars, in turn, contains inlaid stonework with numerous coloured and semi-precious gems set in black limestone or white marble. 


\section{Neoclasicismo}

El yeso sustituyó paulatinamente a la piedra en las fachadas, especialmente durante el resurgimiento arquitectónico que comenzó en el último cuarto del siglo XVIII, cuando se construyeron el Palacio (1772) y la Villa (1790) de Belgiojoso, el Palacio Real (1773) y el Palacio de Serbelloni (1793) y el Teatro de La Scala (1776). Para los pilares, pilastras, zócalos, portales y molduras se utilizaban Ceppo y granito. La caliza de Viggiù, fácil de cincelar, se utilizaba principalmente en balaustradas de balcones y en jambas de ventanas. Los muros de albañilería se hacían con ladrillo enyesado. El Ceppo gentile se utilizaba de manera generalizada en las esculturas que adornaban los jardines de los palacios.

Durante los años de agitación política posteriores a la Revolución Francesa, que dio lugar a la creación de la República Cisalpina (1797), se construyeron pocos edificios dignos de mención. El Anfiteatro Arena (1809), proyectado para celebrar los acontecimientos de la república, se construyó con piedra de fábrica de Ceppo procedente de las desmoronadas estructuras defensivas que rodeaban el Castillo de Sforza, mientras que el arco del triunfo se hizo con granito rosa de Baveno. Otro arco monumental, llamado Arco della Pace o Arco de la Paz, proyectado en honor del emperador Napoleón I (1808) y rediseñado posteriormente para el emperador austriaco Francisco I (1838), se construyó con mármol de Crevola, la misma piedra que puede encontrarse en ocho enormes fustes de columna en el Duomo de Pavía (Figura 9).

Algunas piedras tan sólo duraron unos años debido a su baja resistencia a los agentes atmosféricos. Un claro ejemplo es la arenisca de la Brianza, utilizada para piedra de fábrica, molduras y ornamentos en la Edad Media y de forma generalizada en la arquitectura neoclásica. Su rápido deterioro y la consecuente pérdida de parte del material llevó a que fuera sustituida por caliza de Viggiù.

\section{La unificación de Italia (1861)}

Las últimas décadas del siglo XIX posteriores a la unificación, en las que Italia experimentó el desarrollo del comercio y la finalización de una red ferroviaria, se caracterizaron por una tendencia cada vez mayor a la importación de piedra de otras regiones de Italia. Entre ellas estaban la caliza roja nodular de Verona y la caliza bioclástica de Aurisina, ambas conocidas por los romanos; Marmo di Chiampo (caliza numulítica rosa procedente de los alrededores de Vicenza) (35); granito verde de Mergozzo (graniti dei Laghi) $(9,10)$; y Breccia Seravezza o Breccia Vagli procedente de los Alpes Apuanos (36). Aunque las piedras locales como Ceppo, Ghiandone, granito y la caliza de Viggiù y de Saltrio seguían empleándose en edificios emblemáticos (Galleria Vittorio Emanuele II, 1865-1878, Figura 10), aparecieron por primera vez

\section{Neoclassicism}

Plaster gradually took the place of stone on facades, particularly during the architectural revival that began in the final quarter of the eighteenth century, when the Belgiojoso Palace (1772) and Villa (1790), Royal (1773) and Serbelloni (1793) Palaces and Alla Scala Theatre (1776) were built. Ceppo and granite were used for piers or parastas, socles, portals and mouldings. Readily chiselled Viggiù limestone was used primarily on balcony balustrades and window jambs. Masonry walls were made of plaster-coated brick. Ceppo gentile was used extensively in the sculptures that adorned palace gardens.

Few outstanding buildings were erected during the years of political turmoil that followed the French Revolution, which led to the founding of the Repubblica Cisalpina (1797). The Arena amphitheatre (1809), designed to celebrate Repubblica events, was built with Ceppo dimension stone taken from the fallen defensive structures around Sforza Castle, while the triumphal arch was made of Baveno pink granite. Another monumental arch, called Arco della Pace or Arch of Peace, designed in honour of Emperor Napoleon I (1808) and later re-designed for the Austrian emperor Franz I (1838), was built with Crevola marble, the same stone found on eight huge column shafts in the Duomo at Pavia (Figure 9).

Some stones lasted for only a few years due to their low weather-resistance. A case in point is Brianza sandstone, used for dimension stone, moulding or ornaments in the Middle Ages and extensively in Neo-classic architecture. Its rapid decay and concomitant detachment of part of the material led to its replacement with Viggiù limestone.

\section{Italian unification (1861)}

The latter decades of the nineteenth century following on Italian reunification, which witnessed the development of trade and the completion of a railway network, were characterized by a growing tendency to import stone from other regions of Italy. These included Verona nodular red limestone and Aurisina bioclastic limestone, both used by the Romans; Marmo di Chiampo (pink nummulitic limestone, from around Vicenza) (35); green granite from Mergozzo (Graniti dei Laghi) $(9,10)$; and Breccia Seravezza or Breccia Vagli from the Apuanian Alps (36). Although local stone such as Ceppo, Ghiandone, granite, and Viggiù and Saltrio limestone were still used in emblematic buildings (Galleria Vittorio Emanuele II, 1865-78, Figure 10), other stones from the Lombard region appeared for the first time. These included Urago black and 
otras piedras de la región de Lombardía: conglomerado blanco y negro de Urago (procedente de los alrededores de Como), y caliza roja de Ardesio (28) y arenisca marrón de Credaro (37), ambas procedentes de los Prealpes Bergamascos.

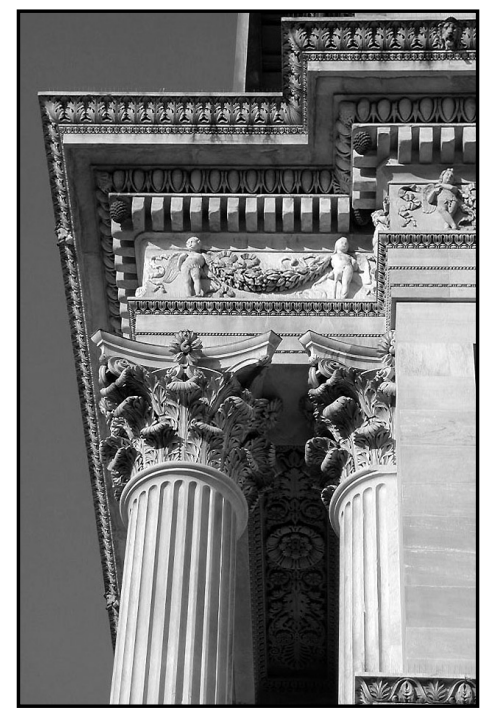

Figura 9. Arco della Pace (L. Cagnola, 1808-1838): detalle del entablamento y los cuerpos de columna en mármol de Crevola y de los capiteles en mármol de Carrara.

Figure 9. Arco della Pace (L. Cagnola, 1808-38). Detail of the Crevola marble entablature and column shafts; Carrara marble capitals.

\section{Modernismo y Art Déco}

A principios del siglo $\mathrm{XX}$, los costes cada vez mayores de la mano de obra provocaron el descenso en la utilización de piedra. Muchas canteras se abandonaron a medida que aumentaba la popularidad de un material menos caro formado por una mezcla de cemento Portland y roca triturada. Además, su aptitud para el moldeo dio lugar a un impresionante despliegue de obras ornamentales. Las fachadas de edificios se adornaban con elementos que mostraban formas planas, curvas o complejas inspiradas en el cuerpo humano, plantas y flores, animales, herramientas y otros objetos. Puesto que se buscaba imitar la piedra natural a la perfección, el color del cemento de base era blanco, gris o rosa, dependiendo de si el tipo de piedra que se deseaba imitar era mármol, caliza o granito. El mejor material para el cemento portland era la caliza margosa del valle de Seriana. La cementera Pesenti (Albino, provincia de Bérgamo) encabezó la investigación para fabricar un tipo especial de cemento pórtland llamado "cemento blanco". También se estudió cuidadosamente la elección del árido con este fin, utilizando para ello fragmentos de dolomía blanca (Botticino) (38), caliza marrón (Viggiù), roja (Verona) o negra (Varenna) y así sucesivamente. La superficie se trabajaba con las mismas white conglomerate (from around Como) and Ardesio red limestone (28) and Credaro brown sandstone (37), both from Bergamasc Prealps.

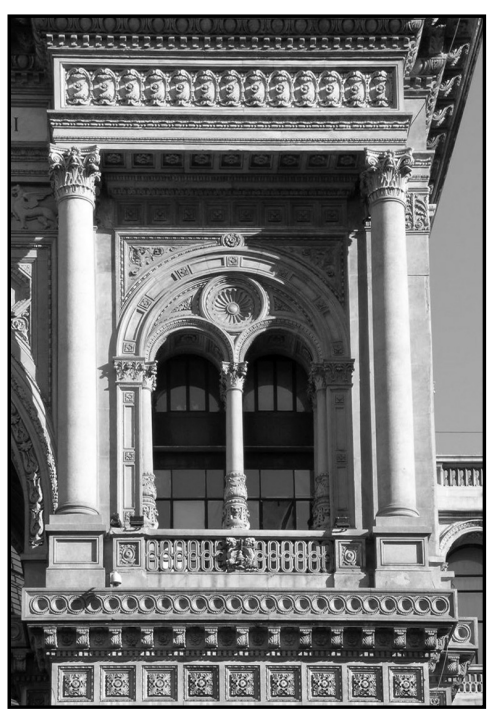

Figura 10. Galleria Vittorio Emanuele II (G. Mengoni, 1878): detalle de las columnas de caliza de Viggiù y de Saltrio, de granito de Baveno (fustes) y de mármol de Carrara (capiteles).

Figure 10. Galleria Vittorio Emanuele II (G. Mengoni, 1878): detail of Viggiù and Saltrio limestone; Baveno granite (shafts) and Carrara marble (capitals) columns.

\section{Liberty and Déco}

In the early twentieth century rising labour costs caused a decline in the use of stone. Many quarries were abandoned as a less expensive material, a mixture of Portland cement and crushed rock, gained popularity. Its mouldability, moreover, led to an impressive array of ornamental work. Building facades were adorned with elements exhibiting flat, curved or complex patterns whose inspiration was the human body, plants and flowers, animals, tools and other objects. Since a perfect imitation of natural stone was sought, the underlying colour of the cement was white, grey or pink, depending on whether the stone to be imitated was marble, limestone or granite. The prime material for Portland cement was the marly limestone found in the Seriana Valley. Pesenti Cementworks (Albino, province of Bergamo) headed research to manufacture a specific kind of Portland cement known as white cement. The choice of aggregate was also carefully studied for this same purpose, using fragments of white dolostone (Botticino) (38), brown (Viggiù), red (Verona) or black (Varenna) limestone, and so on. The surface was worked with the same tools (bushammer or chisel) to produce the same finish (fillet along the edges) as in natural stone. Granite and 
herramientas (bujarda o cincel) para conseguir el mismo acabado (filete en los bordes) que en la piedra natural. En los zócalos se empleaban granito y Ceppo en cumplimiento de las ordenanzas municipales.

Los cambios que se estaban produciendo en las técnicas de construcción contribuyeron asimismo al declive en el uso de piedra. Un ejemplo son los balcones. En los balcones tradicionales ménsulas de granito de Baveno o soportes de acero sostenían losas anchas y estrechas de Beola (un gneis muy foliado que se extraía de Domodossola). En los nuevos balcones las losas de hormigón que servían de plataforma se apoyaban en vigas de hierro envueltas en espirales de piedra artificial.

\section{El periodo de entreguerras: el Fascismo}

El periodo posterior a la Primera Guerra Mundial se caracterizó por la rápida desaparición de lo artificial y un renovado uso de la piedra natural. Muchos arquitectos destacados incluían finas losas de piedra en sus proyectos, en consonancia con las técnicas de construcción contemporáneas (estructura de hormigón armado). Este tipo de estructura se utilizaba en edificios públicos como estaciones de ferrocarril, oficinas de correos, escuelas, hospitales y en los lugares destinados a celebraciones fascistas, así como en casas privadas. Los revestimientos de piedra se serraban de forma precisa y se pulían para resaltar las vetas y puntos de color, y se empleaban principalmente para el recubrimiento de muros o como baldosas. Era común el uso de piedras locales como el mármol de Ornavasso, Crevola y Musso, granito, Serizzo, Ghiandone y Ceppo. La política del gobierno fascista de promover los productos nacionales creó mercado para toda la piedra extraída en Italia. La piedra usada procedente de las antiguas canteras de Lombardía, como Arabescato orobico y
Ceppo were used for socles, pursuant to municipal ordinances.

Changes taking place in building techniques likewise contributed to the declining use of stone. Balconies provide an example. Traditional balconies were made by resting wide and thin slabs of Beola (a heavily foliated gneiss quarried at Domodossola) on Baveno granite corbels or steel supports. The new balconies had reinforced concrete slab platforms that rested on iron beams wrapped in cast stone volutes.

\section{The interwar period: Fascism}

The period following World War I was characterized by the speedy disappearance of artificial and a renewed use of natural stone. Many prominent architects included thin stone slabs in their designs, in keeping with contemporary building techniques (reinforced concrete frame). This type of architecture was used in public buildings such as railway stations, post offices, schools, hospitals and Fascist party premises as well as in private homes. Stone cladding was precision sawn and highly polished to highlight coloured veins and spots, and placed or laid primarily as veneering on walls or floor tiles. Local stone such as Ornavasso, Crevola and Musso marble, granite and Serizzo, Ghiandone and Ceppo was widely used. The Fascist government's policy to promote national products generated a market for all the stone material quarried in Italy. Used stone from former quarries in Lombardy such as Arabescato orobico and Botticino were recycled, and new stone products were identified, including Abbazia (grey limestone with white veins) quarried in Seriana

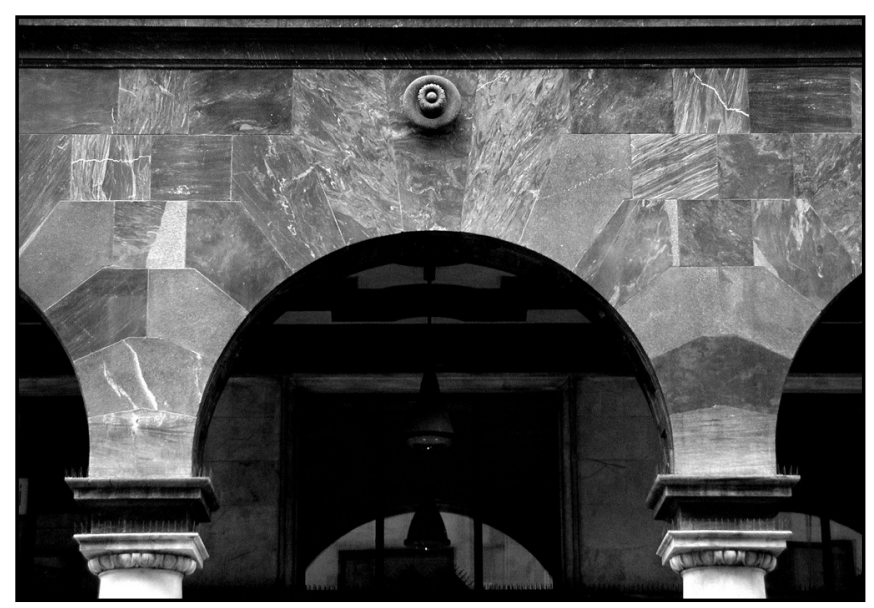

Figura 11. Palazzo Crespi (P. Portaluppi, 1932): detalle de las dovelas de granulita negra (granito nero di Anzola) en el pórtico.

Figure 11. Palazzo Crespi (P. Portaluppi, 1932): detail of the black granulite (known as granito nero di Anzola) voussoirs on the portico. 
Botticino, fue reciclada, y se identificaron nuevos productos como la Abbazia (calcita gris con vetas blancas) extraída en el valle de Seriana, el pórfido violeta y el conglomerado rojo procedentes del valle de Camónica (38), y la piedra verde (serpentinita) procedente de Valtellina (provincia de Sondrio) (39). También se trajo a Milán piedra de otras regiones italianas: Sienite della Balma (Biella) (40); granulita negra de Anzola (Ossola) (41, Figura 11); mármol blanco del valle de Strona (cerca de Ossola) (9); caliza fosilífera rosa de Finale Ligure (provincia de Savona) (42); travertino de Tivoli (Roma) o Rapolano (Siena) (43); piedra verde (oficalcita) de Aosta, Cesana (Piamonte) y Levanto (Liguria) (44); pizarra verde del valle Roja (Liguria); traquita gris de las colinas Euganeas (23); caliza roja nodular de Trento y Asiago (45); mármol veteado o de colores y brecha de los Alpes Apuanos (21) y granito de la isla de Elba (Toscana) (46) y de Gallura (noreste de Cerdeña) (47).

\section{Después de la Segunda Guerra Mundial}

La reconstrucción emprendida para reparar los importantes daños causados por los ataque aéreos (1943-1944) cambiaron el aspecto de Milán, especialmente en el centro de la ciudad. Por ejemplo, en las fachadas de muchas casas privadas se sujetaron mediante acoples metálicos losas rectangulares de Ceppo Poltragno, una brecha con elementos angulosos de caliza y matriz gris porosa extraída cerca del lago Iseo (provincia de Bérgamo) (28). No obstante, el uso de piedra descendió de forma espectacular a medida que el acero y el cristal ganaban la aceptación de los arquitectos.

A pesar de que el uso de revestimientos de piedra experimentó un resurgimiento a finales del siglo $X X$, el uso de piedra local se redujo hasta llegar casi a desaparecer. Las únicas piedras que se extraen actualmente en el valle de Ossola son el Serizzo y el granito.
Valley, purple porphyry and red conglomerate from Camonica Valley (38) and green stone (serpentinite) from Valtellina (province of Sondrio) (39). Stone was also brought to Milan from other regions of Italy, such as Sienite della Balma (Biella) (40); black granulite from Anzola (Ossola) (41, Figure 11); white marble from Strona valley (near Ossola) (9); pink fossiliferous limestone from Finale Ligure (province of Savona) (42); travertino from Tivoli (Rome) or Rapolano (Siena) (43); green stone (ophicalcite) from Aosta, Cesana (Piedmont) and Levanto (Liguria) (44); green slate from Roja Valley (Liguria); grey trachyte from the Euganean Hills (23); nodular red limestone from Trento and Asiago (45); veined or coloured marble and breccia from the Apuanian Alps (21); and granite from Elba Island (Tuscany) (46) and Gallura (northeast Sardinia) (47).

\section{Post-World War II}

The reconstruction undertaken to repair the extensive damage caused by World War II air raids (1943-44) changed the appearance of Milan, primarily in the city centre. Rectangular slabs made from Ceppo Poltragno, a breccia with grey angular limestone elements in a porous grey matrix quarried near Lake Iseo (province of Bergamo) (28), for instance, were attached to the facades of many private homes by means of metallic clamps. The use of stone, however, declined dramatically, as new materials such as steel and glass won the favour of the architectural community.

Although stone in the form of cladding enjoyed a revival in the late twentieth century, the use of local stone dwindled to near disappearance. The only stones quarried in the Ossola Valley today are Serizzo and granite.

\section{BIBLIOGRAFÍA / BIBLIOGRAPHY}

(1) Scamozzi, V.: "L'idea dell'architettura universale", p. 400-402, Venecia, 1615 (cita: Parte 2, libro 7, capítulo 2, página 176)

(2) Breislak, S.: "Descrizione geologica della Provincia di Milano", p. 309, Silvestri, Milán, (1845).

(3) Curioni, G.: "Geologia applicata delle Province Lombarde" - Parte 2, p. 296, Hoepli, Milán, (1877).

(4) Jervis, G.: "I tesori sotterranei dell'Italia - Parte 4", p. 519, Loescher, Turín, (1889).

(5) Salmojraghi, F.: "I materiali naturali da costruzione", p. 454, Hoepli, Milán, (1894).

(6) Peverelli, G., Squarzina, F. (ed.): "I Marmi italiani", p. 453, CFI, Roma, (1939).

(7) Fagnani, G.: "Giacimenti di rocce e minerali utili tra il lago Maggiore ed il lago di Garda", Natura, Vol. 47 (1956), p. 3-55.

(8) Rodolico, F.: "Le pietre delle città d'Italia", p. 502, Le Monnier, Florencia, (1965).

(9) Boriani, A.: "The geo-petrological setting of the Verbano-Ossola domain in the frame of the Alps", Proc. Int. Congr. Quarry-LaboratoryMonument, Vol. 1, p. 1-14, Pavía, (2000).

(10) Veniale, F., Zezza, U.: "Quarrying and properties of the Lago Maggiore Granites", Proc. Meeting ICOMOS, p. 75-98, Pavía, (1986).

(11) Bugini, R., Folli, L.: "Marbles from Lombardy used as building material", Proc. 32nd Int. Geol. Congr. Session T 16.03 - Building and decorative stones, Florencia, (2004).

(12) Ferrari da Passano, C., Zezza, U.: "Exploitation and properties of the Candoglia marble", Proc. Meeting ICOMOS, p. 29-64, Pavía, (1986). 
(13) Zezza, U.: "Il distretto estrattivo del Verbano-Ossola. I marmi ossolani", I materiali lapidei -Pietre ornamentali, 1a Scuola di Petrografia Univ. Bari, p. 22-27, Trani, (1997).

(14) Lualdi, A., Zezza, U.: "Stones from the Varese territory in historical use of lombard architecture", Proc. Int. Congr. Quarry-LaboratoryMonument, Vol. 1, p. 397-402, Pavía, (2000).

(15) Soggetti, F., Zezza, U.: "Coltivabilità e proprietà tecniche della pietra di Angera (Lago Maggiore)". Geol. Appl. e Idrogeol., Vol. 18 (1983), p. 81- 93.

(16) Fernandez, D.: "Depositi di correnti di torbidità nelle Prealpi bergamasche - Le arenarie del Cretacico Superiore (Coniaciano)", Atti Soc. It. Scienze Nat., Vol. 102, (1963), p. 83-122.

(17) Trommsdorf, V., P. Nievergelt: "The Bregaglia (Bergell)-Iorio intrusive and its field relations", Mem. Soc. Geol. It., Vol. 26-1, (1983), p. $55-68$.

(18) Marinoni, N., Pavese, A., Bugini, R., Di Silvestro, G.: "Black limestone used in lombard Architecture", Journal of Cultural Heritage, Vol. 3, (2002), p.241-249.

(19) Orombelli, G.: "Il Ceppo dell'Adda - Revisione stratigrafica", Riv. Ital. Paleont., Vol. 85-2, (1979), p. 573-652.

(20) Zezza, U., Veniale, F.: "Use and decay of Ceppo stone in monuments of Lombardy (Northern Italy)", Proc. 5th Int. Congr. Deterioration and Conservation of Stones, Vol. 1, p. 351-360, Lausana, (1985).

(21) Carmignani, L.: Carta geologico-strutturale del complesso metamorfico delle Alpi Apuane, CNR, Florencia, (1996).

(22) Lazzarini, L.: "Archaeometric aspects of white and coloured marbles used in antiquity: the state of the art", Per. Mineral., Vol. 73 (2004), p. 113-125.

(23) Piccoli, G., Sedea, R., Bellati, R., Di Lallo, E., Medizza, F., Girardi, A., De Pieri, R., De Vecchi, G., Gregnanin, A., Piccirillo, E. M., Norinelli, A., Dal Pra, A.: Note illustrative della carta geologica dei Colli Euganei, CNR, Padua, (1981).

(24) Bortolaso, G., Lazzarini, L., Menegazzo, L., Rampazzo, G.: "The deterioration of Rosso Ammonitico Veronese nodular limestone: comparison between a quarry and a venetian monument", Proc. 6th Int. Congr. Deterioration and Conservation of Stone, p. 97-109, Torun, (1988).

(25) Lazzarini. L. (ed.): Pietre e marmi antichi, p. 196, Cedam, Padua, (2004).

(26) Fiumara, A., Riganti, V., Veniale, F., Zezza, U.: "Sui trattamenti conservativi della pietra d'Angera", Proc. 3rd Int. Congr. Deterioration and Conservation of Stone, p. 339-356, Venecia, (1979).

(27) Repishti, F. (ed.): La facciata del Duomo di Milano (1582-1750), p. 64, Unicopli, Milán, (2002).

(28) Jadoul, F., Forcella, F. (ed.): Carta geologica della provincia di Bergamo, Provincia di Bergamo, Bérgamo, (2002).

(29) Assereto, R., Casati, P.: "Revisione della stratigrafia permo-triassica della Val Camonica meridionale", Riv. Ital. Paleont., Vol. 71-4 (1965), p. 999-1097.

(30) Giannini, E., Lazzaretto, A.: "Studio geologico della Montagnola Senese", Mem. Soc. Geol. It, Vol. 9 (1970), p. 451-495.

(31) Bourrouilh, R., Bourque, P. A.: "Les calcaires à stromatactis de type marbre rouge Languedoc", ASMOSIA IV, p. 65-76, Burdeos (1995).

(32) Falcone, R., Lazzarini, L.: "Note storico-scientifiche sul Broccatello di Spagna", Studi miscellanei 31. L'Erma di Bretschneider, p. 87-98 (1998).

(33) Paganoni, A., Camerlenghi, A.: "La collezione A. Galletti", Riv. Museo Scienze Nat. Bergamo, Vol. 12, (1987), p. 4-59.

(34) Fiora, L., Ferrarese, P.: "I marmi verdi della Valle d'Aosta", L'Informatore del Marmista, Vol. 436, (1998), p. 6-14.

(35) Dal Piaz, G.V. (ed.): Carta Geologica del Veneto, Regione Veneto, Venecia, (1990).

(36) Lazzarini, L., Turi, B.: "Characterization and Differentiation of the Skyros Marbles (Greece) and the Medici's breccias (Italy)", ASMOSIA IV, p.117-123, Burdeos, (1995).

(37) Bettoni, M., Madesani, R., Paganoni, A.: La Pietra di Credaro, p. 96, CCPC, Bérgamo, (1997).

(38) Boni, A., Cassinis, G.: "Carta geologica delle Prealpi bresciane a Sud dell'Adamello - Note illustrative della legenda stratigrafica", Atti Ist. Geol. Univ. Pavia, Vol. 23 (1973), p. 119-159.

(39). Bigioggero, B., Colombo, A., Guerra, S., Montrasio, A., Tunesi, A.: "Le pietre verdi di Valtellina e Chiavenna", Proc. Int. Congr. QuarryLaboratory-Monument, Vol. 2, p. 9-14, Pavía, (2000).

(40) Flora, L., Fornaro, M., Manfredotti, L.: "Impiego della sienite piemontese nell'arredo urbano - Tradizione, attualità, prospettive", Proc. Int. Congr. Quarry-Laboratory-Monument, Vol. 1, p. 299-308, Pavía, (2000).

(41) Bigioggero, B., Zezza, U.: "Il distretto estrattivo del Verbano-Ossola", I materiali lapidei, con particolare riferimento alle pietre ornamentali, 1a Scuola di Petrografia Univ. Bari, p. 41-55, Trani, (1997).

(42) Boni, P., Mosna, S., Vanossi, M.: "La Pietra di Finale (Liguria occidentale)", Atti Ist. Geol. Univ. Pavia, Vol. 18 (1968), p. $102-150$.

(43) Cipriani, C., Malesani, P. G.y Vannucci, S.: "I travertini dell'Italia centrale", Boll. Serv. Geol. Ital., Vol. 98 (1977), p. 85-115.

(44) Di Pierro S., Fiora, L.: "Caratterizzazione petrografica della oficalcite Verde Cesana e di potenziali rocce oficarbonatiche sostitutive", Atti 5 a Giornata Le scienze della terra e l'archeometria, p. 99-108, Bari, (1998).

(45) De Vecchi, G. P., Perna, E., Perna, G., Ventrini, P.: "Le pietre del Trentino (problemi connessi alla loro degradazione)", Proc. 3rd Int. Congr. Deterioration and Conservation of Stone, p. 135-152, Venecia, (1979).

(46) Lazzarini, L.: "I graniti dei monumenti italiani e i loro problemi di deterioramento". Bollettino d'Arte, suppl. Vol. 41 (1987), p. $157-172$. (47) Carmignani, L. (ed.): "Geologia della Sardegna. Note illustrative della Carta Geologica della Sardegna", Mem. Descr. Carta Geol. Italia, Vol. 60, (2001). 